\title{
Tech Yoga: An Introduction to an Exclusive Combination of Technology and Yoga
}

\author{
Kshitij Shinghal* \\ Department of Electronics \& Communication engineering, Moradabad Institute of Technology, India
}

Submission: December 18, 2017; Published: January 05, 2018

*Corresponding author: Kshitij Shinghal, Associate Professor, Department of Electronics \& Communication engineering, Moradabad Institute of Technology, Moradabad, UP, India, Email: kshinghal@gmail.com

\section{Editorial}

Given an opportunity to write an editorial opinion for Journal of Yoga and Physiotherapy (JYP), I acknowledge the contribution of all the author's, reviewers, editors and other team members of the journal. I am thankful to all contributor's for submitting their valuable research works. Yoga is an age-old discipline which means union, connect, join or balance the physical, mental, and spiritual practices. Tech-yoga is latest development in field of yoga. Tech-yoga is the terminology which means giving this ageold practice a modern spin i.e. integrating technology with yoga to make practicing yoga more easy and comfortable. Tech-yoga has encouraged even more people to give yoga a try especially the youth. Technology has played a role in this increase, having made yoga more accessible, and with a click put millions of practitioners from all over the world in touch. Tech-yoga is good as it gets more and more people doing yoga throughout the world. Some of the high-tech integration with yoga are yoga Apps, yoga software, high-tech gear, yoga clothing, yoga video games.

For Tech-yoga enthusiasts, there are several products available in the market which will enhance their experience of yoga through technology. Aside from apps and websites dedicated to yoga, there are several hardware devices which serve the purpose. Here are a few technological advances that are making rollers within the tech-yoga community.

\section{Yoga apps}

Tons of yoga apps are available online that teach all kinds of yoga, which help you set specific goals, challenge friends, share progress, make your own yoga community, blogs etc. Further these apps can pair with several hardware gadgets for improving your yoga experience. These apps can easily be paired with sensor integrated yoga pants, yoga mats, yoga bags, shoes etc. for data collection.

\section{Yoga software}

There are yoga software that helps you design yoga routines. There's also yoga software that helps yoga studios and yoga teachers run their yoga businesses. Both types of yoga software help end-users tremendously.

\section{Yoga DVDs or Online yoga streaming}

DVDs or online yoga streaming video can be watched any time in the convenience of own home. Moreover, some people starting yoga may not feel comfortable going to a class but want to start yoga. Yoga DVDs is a terrific way to introduce people to yoga.

\section{High-tech yoga gear}

Sensor woven high-tech yoga Gear is becoming more and more popular among tech-yoga enthusiasts. A few popular hightech yoga gear are yoga bags, accessories, such as yoga mats, blocks, bolsters etc. These High-Tech Yoga Gear can easily be paired with yoga guidance apps, software etc.

\section{Yoga clothing}

The latest yoga clothing helps us improve our practice and increases our comfort during yoga sessions by weaving sensors into yoga garments, such as yoga pants, shirts, and even shoe. These sensors senses and transmits the data about your body and positioning. Tech-yoga clothes can be paired with a corresponding app smartphone or tablet, which receives and process the data from the sensors. On the basis of this data the yoga apps can give you guidance about your practice.

\section{Yoga video games}

Another latest trend in Tech-yoga is yoga video games. In yoga video games, you do yoga moves following along with a video game. In this way, you do yoga along with entertainment. 
This technique may become effective to introduce and make yoga popular among youth. Integrating yoga with technology will result in creating an entirely new market of tech-savvy practitioners-internationally. This will not only help in creating awareness about yoga but also promote yoga thereby increasing total number of yoga practitioners: Yogis.

The "Journal of Yoga and Physiotherapy (JYP)" is a very good platform for disseminating research work, ideas and innovations at internationally recognized platform. It is a multidisciplinary, international peer reviewed journal and is dedicated to promote spread the information in yoga and physiotherapy that seeks original research papers, review articles, mini- reviews, short communication, opinions, letters to editors etc. It invites papers related to yoga and physiotherapy is Yoga is the practice of attaining physical and mental health through meditation and physical exercise. Journal is dedicated to publish research in physiotherapy and spiritual practice followed in various regions of the world. The journal aims to publish original and clinically relevant research in topics related to Physiotherapy and other related fields in the health care community thus it promotes international readership. It focuses on international assembly for encouraging noble discussions and thus contributing for best treatment aids for the yoga and physiotherapy to the needy and also benefiting readers and authors by accelerating the dissemination of research information providing maximum access to advanced current academic and clinical information through Evidence based practice. It aims at rapid publication of high quality research, reviews and short communications

This work is licensed under Creative Commons Attribution 4.0 License DOI: 10.19080/JYP.2018.03.5555619 and provides free access of the articles for the students, academicians, clinicians for future research. It also focuses on highest quality scientific papers and review articles of interest to academic and industrial researchers. The journal covers the entire range of topics related to Physiotherapy, from theoretical advances to relevant and sensible translations of a practical problem into a statistical framework, including advances in yoga and physiotherapy. Its main focus is on covering recent developments in areas of Yoga and Physiotherapy. JYP opens the door for reproducible research allowing readers to easily replicate analysis described in papers. Please contribute articles to this journal in a timely manner, to ensure it gets published timely and becomes part of this important forum for the exchange of ideas and knowledge which will ultimately translate to better technological exchange of information among peers. If you have any questions or comments about the Journal, please contact at jyp@juniperpublishers.com, jyp@juniperpublishers.org, jyp@ juniperpublishers.us The Journal is available online, please visit the following website: http://juniperpublishers.com/jyp/

\section{References and Acknowledgement}

I have based this paper on the materials collected from several courses I've attended. It is inspired by many Guidelines for Authors of various reputed international journals. Some of this information is also featured in various tutorials available online. In addition, I have consulted several web pages, blogs etc. for shaping this article. I would like to thank Mr. Amit Saxena and Ms. Deepti Shinghal for their valuable support, without their help this article would have been impossible to complete.

Your next submission with Juniper Publishers
will reach you the below assets
- Quality Editorial service
- Swift Peer Review
- Reprints availability
- E-prints Service
- Manuscript Podcast for convenient understanding
- Global attainment for your research
- Manuscript accessibility in different formats
( Pdf, E-pub, Full Text, Audio)
- Unceasing customer service
Track the below URL for one-step submission
https://juniperpublishers.com/online-submission.php

